\title{
A diagnostically difficult case of chronic myeloid neoplasm with eosinophilia and abnormalities of PDGFRA effectively treated with imatinib in accelerated phase
}

\author{
Marek Rodzaj', Krystyna Gałązka², Mirosław Majewski³ ${ }^{3}$ Andrzej Zduńczyk \\ 1 Department of Hematology and Internal Diseases, Rydygier Hospital, Kraków, Poland \\ 2 Department of Patomorphology, Jagiellonian University School of Medicine, Kraków, Poland \\ 3 Institute of Hematology and Transfusion Medicine, Warszawa, Poland
}

\section{KEY WORDS}

chronic myeloid neoplasm with eosinophilia and abnormalities of PDGFRA, imatinib
Correspondence to:

Marek Rodzaj, MD, Oddział Hematologii i Chorób Wewnętrznych, Wojewódzki Szpital Specjalistyczny im. L. Rydygiera, os. Ztotej Jesieni 1 , 31-826 Kraków, Poland, phone: +48-12-646-82-20, fax: + 48-12-646-89-46, e-mail: rodzaj@mp.pl Received: September 15, 2009. Revision accepted: November 12, 2009. Conflict of interest: none declared. Pol Arch Med Wewn. 2009; 119 (12): 838-841

Copyright by Medycyna Praktyczna, Kraków 2009

\begin{abstract}
Chronic myeloid neoplasm with eosinophilia and abnormalities of platelet-derived growth factor receptor a (PDGFRA), referred to until 2008 as chronic eosinophilic leukemia, is distinguished from hypereosinophilic syndrome (HES), if accompanied by genetic abnormalities that enable to determine eosinophil clonality. Typically, HES has a benign course and glucocorticosteroids suffice to achieve remission. In chronic myeloid neoplasm with eosinophilia and abnormalities of PDGFRA the FIP1L1-PDGFRA fusion gene can be detected. Its product is a protein showing tyrosine kinase activity leading to malignant proliferation of eosinophil precursors. Differential diagnosis of HES is often difficult because hypereosinophilia may also be reactive and may occur in many nonhematological as well as hematological disorders. Thus, reverse-transcription polymerase chain reaction (RT-PCR) is indicated in all patients with HES in order to detect the FIP1L1-PDGFRA transcript. Traditional treatment of chronic myeloid neoplasm with cytostatic drugs results in a short-term and transient remission or stabilization of the disease.

We present the case of a 52-year-old patient with chronic myeloid neoplasm with eosinophilia and abnormalities of PDGFRA, in whom acceleration occurred after a year of cytostatic therapy with hydroxyurea and was successfully treated with imatinib. It was impossible to unequivocally determine the type of bone marrow disease based on histologic criteria, and a wide spectrum of molecular tests differentiating the type of myeloid proliferation were necessary to establish the diagnosis. RT-PCR did not reveal $B C R-A B L$ or JAK2 V617F mutation. Further molecular testing showed rearrangement involving the FIP1L1 gene, thus enabling implementation of targeted therapy.
\end{abstract}

INTRODUCTION Chronic myeloid neoplasm with eosinophilia and abnormalities of platelet-derived growth factor receptor $\alpha$ (PDGFRA) had been referred to as chronic eosinophilic leukemia (CEL), until the World Health Organization published a new classification of tumors of hematopoietic and lymphoid tissues in 2008. It occurs very rarely and is distinguished from hypereosinophilic syndrome (HES), if accompanied by genetic disorders that indicate eosinophil clonality. The term "HES" was introduced in 1968 by
Hardy and Anderson. ${ }^{1,2}$ It occurs more often in men than in women (9:1), mainly in subjects aged 20 to 50 years. ${ }^{1-3}$

The disease is characterized by deletion on chromosome 4: del(4)(q12;q12), which accounts for the formation of a fusion gene consisting of the PDGFRA and FIP1L1 (FIP1-like-1) genes. ${ }^{1-4}$ $\operatorname{Del}(4)$ is not detectable using conventional cytogenetic techniques. Reverse-transcription polymerase chain reaction (RT-PCR) demonstrated the prevalence of the FIP1L1-PDGFRA fusion gene 


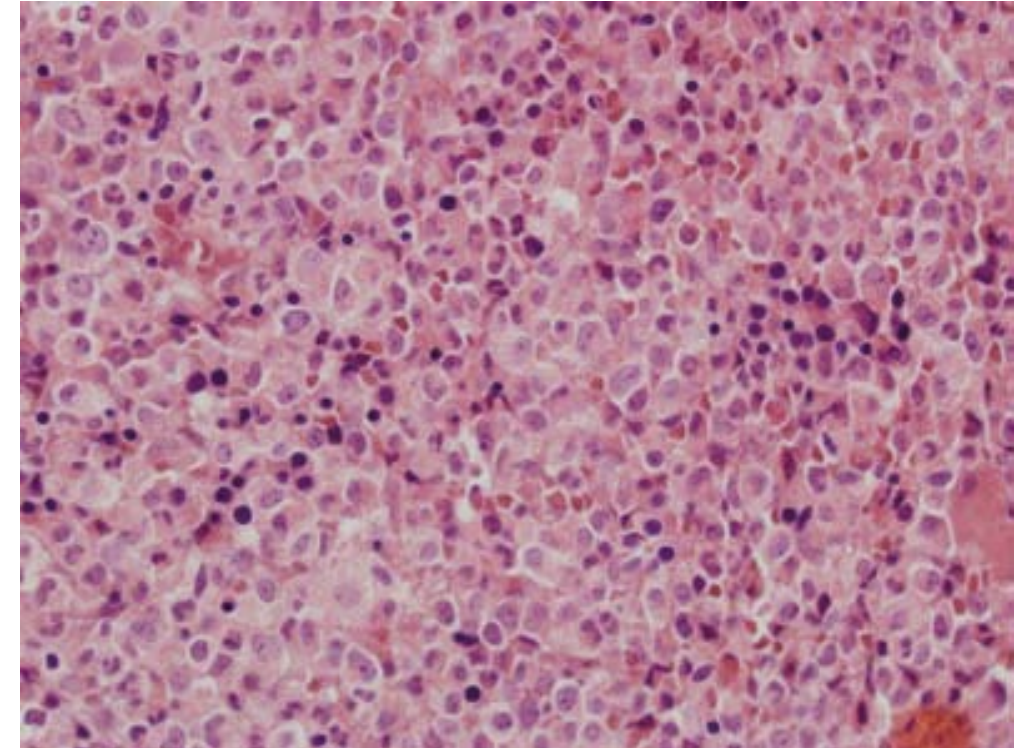

FIGURE Less mature cells, but with no significant blast count. Bands and segmented neutrophils are present with maturing granulocytes. In this area of a bone marrow bioptate, there was no significantly increased percentage of eosinophilic cells. Visible erythropoiesis (a clearly distinct isle in the center-right region of the image) without traits of dyserythropoiesis. Hematoxylin and eosin staining.

Magnification $\times 60$. in about $10 \%$ to $15 \%$ of patients with chronic myeloid neoplasm with eosinophilia and abnormalities of PDGFRA. ${ }^{5-7}$ The protein which is produced as a result of this chromosomal aberration has an increased tyrosine kinase activity, which causes neoplastic transformation of hematopoietic cells. Eosinophil precursors release proinflammatory cytokines, mediators derived from arachidonic acid, and enzymes toxic to surrounding tissues. Eosinophilic infiltration occurs in various organs leading to their damage. This causes a whole spectrum of accompanying symptoms, both general and related to pathologies of the cardiovascular, respiratory, nervous, and gastrointestinal systems and to skin lesions. ${ }^{8}$

Eosinophilia may be reactive and may occur in numerous nonhematological diseases (allergies, parasitic diseases, systemic connective tissue diseases, and others). It may also accompany a number of hematological diseases, including T-cell lymphomas, Hodgkin's lymphoma, mastocytosis, myelodysplastic syndromes, and other myeloproliferative disorders. For this reason, differential diagnosis may be challenging and painstaking.

CASE REPORT In December 2006, a 52-year-old patient was diagnosed with splenomegaly, leukocytosis $\left(27,000 / \mathrm{mm}^{3}\right)$ with an increase in younger forms including promyelocytes and eosinophilia (33\%), and lactate dehydrogenase (LDH) of $215 \mathrm{U} / \mathrm{l}$. Abdominal ultrasound showed enlarged spleen up to $20 \mathrm{~cm}$, and a $15 \times 12 \mathrm{~mm}$ lymph node in the hepatic hilus. There were no abnormalities in other organs (chest X-ray was normal, there were no skin lesions). Histologic examination of a bone marrow bioptate showed features of a bone marrow neoplasm, suggesting either myelodysplastic syndrome or myeloproliferative disease, with emphasis on chronic myelomonocytic leukemia or an atypical chronic myeloid leukemia (CML), but with an increased percentage of eosinophilic granulocyte forms (there was an in- creased percentage of eosinophils, but neutrophils were predominant) and mast cells (FIGURE).

It was impossible to unequivocally diagnose the type of disease based on histologic criteria, and it was necessary to perform a wide spectrum of molecular tests. Cytogenetic analysis of the bone marrow by G-banding method revealed a normal karyotype. RT-PCR did not detect $B C R-A B L$ p210 t $(9 ; 22)(\mathrm{q} 34 ; \mathrm{q} 11)$. The examination of fine-needle biopsy of the spleen yielded inconclusive results. Granulocyte alkaline phosphatase activity was 6 points.

Given an ambiguous clinical presentation, an unclassified myeloproliferative syndrome was diagnosed in April 2007. Cytoreductive therapy was initiated ( $1 \mathrm{~g}$ hydroxyurea [HU]) due to the size of the spleen and hyperleukocytosis with younger stages inluding myeloblasts (4\%). Complementary genetic tests for the JAK2 V617F mutation and FIP1L1 gene rearrangement were performed. Cytogenetics was repeated.

Further molecular testing using RT-PCR enabled to identify the FIP1L1-PDGFRA fusion gene associated with $\operatorname{del}(4)$ (q12;q12). JAK2 V617F mutation was not detected. Cytogenetic analysis of peripheral blood using the G-banding method revealed 46XY, del(7)(q22) karyotype. Repeat histologic evaluation of the bone marrow and analysis of genetic tests resulted in the diagnosis of chronic myeloid neoplasm with eosinophilia and abnormalities of PDGFRA in March 2008. It is important to note that this diagnosis was based, above all, on molecular analysis, which revealed the presence of aberration that was typical and highly characteristic of CEL, with coexisting peripheral hyperleukocytosis (it rose to $54,000 / \mu \mathrm{l}$ ) and hypereosinophilia (it increased from 33\% to $41 \%$ ). The histologic examination of the bone marrow (despite an increase in the percentage of eosinophilic forms) did not provide conclusive evidence to establish the diagnosis. Detection of FIP1L1-PDGFRA rearrangement results in effective treatment with tyrosine kinase inhibitors (imatinib, dasatinib, nilotinib) because the product of this gene is 100 times more sensitive to imatinib than $B C R-A B L$.

In April 2008, despite HU therapy, the patient's state deteriorated. The following symptoms were observed: weight loss, body temperature $38^{\circ} \mathrm{C}$, fatigue, dyspnea at rest, dry cough, and peripheral edema. Laboratory tests revealed increased leukocytosis to $168,000 / \mathrm{mm}^{3}$, hemoglobin $9.4 \mathrm{~g} / \mathrm{dl}$, a decrease in platelet count to $61,000 / \mathrm{mm}^{3}$, an increase in the percentage of peripheral blastic cells to $8 \%$, and a decrease in the percentage of eosinophils to $4 \%$. Cytological assessment of the marrow showed signs of disease acceleration, abnormal plasma coagulation tests (prothrombin index - $72 \%$, international normalized ratio -1.31 , ac tivated partial thromboplastin time $-36.6 \mathrm{sec}-$ onds, fibrinogen concentration - $4.63 \mathrm{~g} / \mathrm{l}$ ), hypoalbuminemia, an elevation of LDH to $482 \mathrm{U} / 1$ Radiogram of the chest demonstrated a small amount of fluid in the pleural cavities, as well 
as hepatosplenomegaly. During escalation of cytoreductive therapy ( $3 \mathrm{~g} \mathrm{HU})$, further progression of the disease was noted, with deterioration of the patient's condition, and a rise in leukocytosis to $255,000 / \mathrm{mm}^{3}$. 6-merkaptopurine was administered at a dose of $100 \mathrm{mg} /$ day.

We decided that the patient should receive $100 \mathrm{mg}$ of imatinib daily. This led to improvement of his state, resolution of all symptoms, a decrease in leukocytosis to $1500 / \mathrm{mm}^{3}$, and reduced hepatosplenomegaly. Subsequently, the dose of imatinib was reduced to $100 \mathrm{mg}$ twice a week, which improved the patient's general condition, normalized blood cell counts, and reduced spleen size (to $136 \mathrm{~mm}$ ).

DISCUSSION Imatinib, due to inhibition of tyrosine kinase, proved useful not only in the treatment of chronic myeloid leukemia, but also in the treatment of chronic myeloid neoplasm associated with eosinophilia and abnormalities of PDGFRA, chronic myeloproliferative syndromes with ETV6-PDGFRB gene rearrangement, $\mathrm{Ph}+$ acute lymphoblastic leukemia, and gastrointestinal stromal tumors. ${ }^{4}$ However, in some patients with HES, FIP1L1-PDGFRA and ETV6-PDGFRB gene rearrangement was not detected. Despite this, imatinib therapy was successful, which might indicate the presence of undiagnosed chromosomal aberrations that increase tyrosine kinase activity. ${ }^{2-4}$ Detection of FIP1L1-PDGFRA mutation allows to identify a group of patients with a good response to treatment with low doses of imatinib. $^{4}$

The accessibility of modern therapy poses a greater diagnostic challenge - it is necessary to precisely determine the type of neoplastic disorders, which sometimes requires molecular diagnostic testing, as was the case in our patient. It should be emphasized that these tests are particularly important and largely conclusive in the diagnosis of eosinophil clonality, because these disorders quite often do not display any cytological or histological bone marrow abnormalities that are characteristic enough to distinguish them from reactive eosinophilia. They may also be accompanied by anomalies that suggest a quite different disease, e.g., an increase in mast cells, including those showing abnormal fusiform morphologic features (which in our patient was detectable in histopathologic examination of the bone marrow). This pathology may be associated with increased serum mast cell tryptase levels, and it might be entirely reactive by nature in chronic myeloid neoplasm with eosinophilia and abnormalities of PDGFRA.

Progress in genetic testing, increased accessibility of genetic tests, and the introduction of new molecularly targeted agents allow us to prolong the lives of patients while ensuring a significantly lower risk of therapeutic failure and less side effects.

\section{REFERENCES}

1 Hellmann A, Prejzner W. [Hypereosinophilic syndrome and chronic eosinophilic leukemia]. In: Szczeklik A, ed. Internal Diseases. Vol. 2. Kraków: Medycyna Praktyczna; 2005: 1500-1503. Polish.

2 Jovanovic JV, Score J, Waghorn K, et al. Low-dose imatinib mesylate leads to rapid induction of major molecular responses and achievement of complete molecular remission in FIP1L1-PDGFRA-positive chronic eosinophilic leukemia. Blood. 2007; 109: 4635-4640.

3 Prejzner W, Szatkowski D, Wasag B, et al. [Targeted imatinib therapy in a patient with chronic eosinophilic leukemia]. Współczesna onkologia. 2005; 9: 7-10. Polish

4 Helbig G, Stella-Hołowiecka B, Majewski M, et al. A single weekly dose of imatinib is sufficient to induce and maintain remission of chronic eosinophilic leukaemia in FIP1L1-PDGFRA-expressing patients. Br J Haematol. 2008; 141: 200-204

5 Cools J, DeAngelo DJ, Gotlib J, et al. A tyrosine kinase created by fusion of the PDGFRA and FIP1L1 genes as a therapeutic target of imatinib in idiopathic hypereosinophilic syndrome. N Engl J Med. 2003; 348 : 1201-1214.

6 Vandenberghe $\mathrm{P}$, Wlodarska I, Michaux L, et al. Clinical and molecular features of FIP1L1-PDFGRA $(+)$ chronic eosinophilic leukemias. Leukemia. 2004; 18: 734-742.

7 Pardanani A, Brockman SR, Paternoster SF, et al. FIP1L1-PDGFRA fusion: prevalence and clinicopathologic correlates in 89 consecutive patients with moderate to severe eosinophilia. Blood. 2004; 104: 3038-3045.

8 Gotlib J, Cools J, Malone JM, et al. The FIP1L1-PDGFRalpha fusion tyrosine kinase in hypereosinophilic syndrome and chronic eosinophilic leukemia: implications for diagnosis, classification, and management. Blood 2004; 103: 2879-2891. 


\title{
Trudny diagnostycznie przypadek chorego na przewlekły nowotwór mieloproliferacyjny z eozynofilią i rearanżacją PDGFRA, skutecznie leczonego imatynibem w fazie akceleracji
}

\author{
Marek Rodzaj', Krystyna Gałązka², Mirosław Majewski ${ }^{3}$, Andrzej Zduńczyk ${ }^{1}$ \\ 1 Oddziat Hematologii i Chorób Wewnętrznych, Wojewódzki Szpital Specjalistyczny im. L. Rydygiera, Kraków \\ 2 Zakład Patomorfologii, Uniwersytet Jagielloński, Collegium Medicum, Kraków \\ 3 Instytut Hematologii i Transfuzjologii, Warszawa
}

\section{SŁOWA KLUCZOWE}

imatynib, przewlekły nowotwór mieloproliferacyjny z eozynofilią i rearanżacją PDGFRA

\section{STRESZCZENIE}

Przewlekły nowotwór mieloproliferacyjny z eozynofilią i rearanżacją PDGFRA (platelet-derived growth factor receptor a), określany do 2008 roku jako przewlekła białaczka eozynofilowa (chronic eosinophilic leukemia - CEL), jest wyodrębniany z zespołu hipereozynofilowego (hypereosinophilic syndrome - HES), jeśli towarzyszą mu zaburzenia genetyczne pozwalające stwierdzić klonalność rozrostu. HES ma zwykle tagodny przebieg, a glikokortykoidy wystarczają do uzyskania poprawy. W przewlekłym nowotworze mieloproliferacyjnym z eozynofilią i rearanżacją PDGFRA wykrywa się gen fuzyjny FIP1L1-PDGFRA, którego produktem jest białko 0 aktywności kinazy tyrozynowej powodujące nowotworową proliferację prekursorów eozynofili. Diagnostyka różnicowa w HES jest często bardzo trudna, ponieważ hypereozynofilia może mieć także charakter odczynowy i występować $w$ wielu niehematologicznych $i$ hematologicznych jednostkach chorobowych. Wskazane jest więc badanie RT-PCR (reverse-transcription polymerase chain reaction) u wszystkich chorych z HES w celu wykrycia transkryptu FIP1L1-PDGFRA. Tradycyjne leczenie choroby lekami cytostatycznymi przynosi krótkotrwałą i przejściową poprawę lub stabilizację choroby.

Poniżej opisujemy przypadek 52-letniego chorego z przewlekłym nowotworem mieloproliferacyjnym z eozynofilią i rearanżacją PDGFRA, u którego po roku leczenia cytostatycznego hydroksymocznikiem wystąpiła akceleracja rozrostu skutecznie leczona imatynibem. Ponieważ w oparciu o kryteria histologiczne niemożliwe było jednoznaczne określenie typu choroby szpiku kostnego, do postawienia diagnozy konieczna okazała się szeroka gama badań molekularnych różnicujących charakter proliferacji szpikowej. W badaniu metodą RT-PCR nie wykryto mutacji $B C R-A B L$, nie wykryto też mutacji V617F genu JAK2. Dalsza diagnostyka zmian molekularnych pozwoliła wykryć rearanżację z udziałem genu FIP1L1, co pozwoliło wdrożyć leczenie celowane. 


\section{Zamówienia na recepty}

Zamówienia można składać:

n pod adresem: recepty.mp.pl

telefonicznie: (012) 2934088

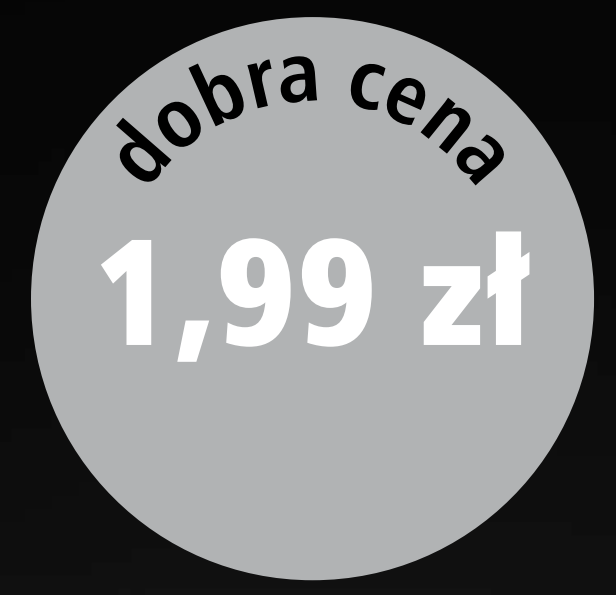

cena: 1,99 zł $+22 \%$ VAT za bloczek recept (100 sztuk)*

Zamówione recepty wysyłamy w ciągu 2-3 dni.

Możliwa realizacja ekspresowa (1 dzień roboczy) za dopłatą $50 \%$.

* plus koszt przesyłki kurierskiej $-12,50$ zł $+22 \%$ VAT

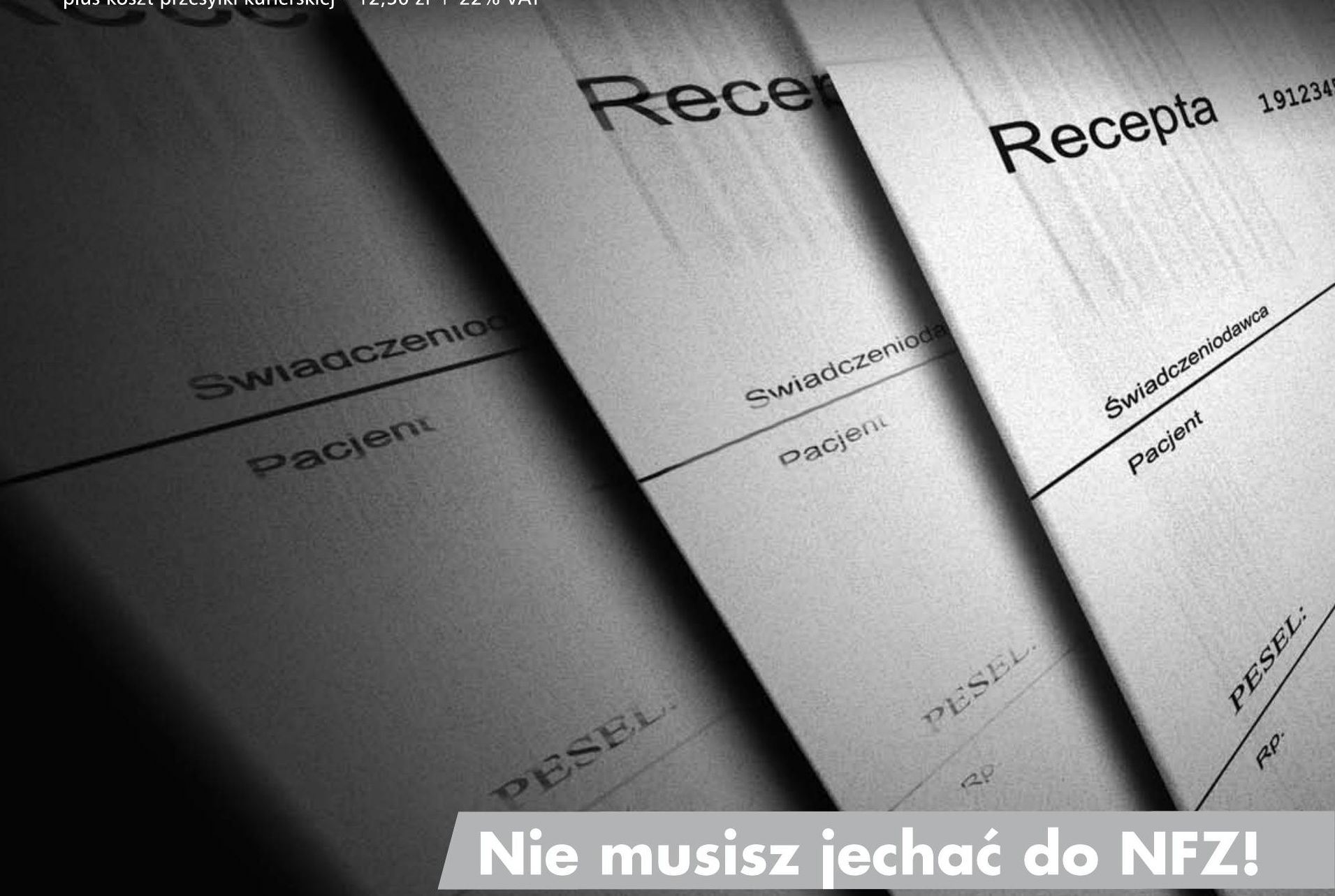

medycyna proktyczina 